\title{
DISTRIBUTION, RECENT MORTALITIES AND CONSERVATION MEASURES OF CRAYFISH IN HELLENIC FRESH WATERS
}

\author{
E. KOUTRAKIS (1), C. PERDIKARIS (2), Y. MACHINO (3), G. SAVVIDIS (4) and \\ N. MARGARIS (5)
}

(1) Fisheries Research Institute, National Agricultural Research Foundation, GR-64007, Nea Peramos, Kavala, Greece.

E-Mail: manosk@inale.gr

(2) Department of Aquaculture \& Fisheries, Technological Educational Institute of Epirus, Irinis \& Filias 1, GR-46100 Igoumenitsa, Greece.

E-Mail: kperdik@otenet.gr

(3) Higashi-Monzen-cho 520-4, Sakyo-ku, Kyoto 606-8345, Japan.

E-Mail: yoichi.machino@fnac.net

(4) Veterinary Research Institute, National Agricultural Research Foundation, NAGREF Campus, PO Box 60272, GR-57001 Thermi, Thessaloniki, Greece. E-Mail: savvidis.vri@nagref.gr

(5) Department of Environmental Studies, University of the Aegean, University Hill, GR-81100, Mytilene, Greece.

E-Mail: margaris@dolnet.gr

Reçu le 8 février 2007

Accepté le 11 juin 2007

Received February 8, 2007

Accepted June 11, 2007

\section{ABSTRACT}

Freshwater crayfish are found in 20 out of 53 Prefectures of Greece (38\%) and they form isolated populations in relatively pristine water bodies. Three indigenous crayfish species (ICS) occur in Greek waters: Astacus astacus, Astacus leptodactylus and Austropotamobius torrentium, as well as one non-indigenous crayfish species (NICS) Pacifastacus leniusculus. Greece represents probably the most southern natural distribution limit for $A$. astacus and A.torrentium in the world. Concerning NICS, $P$. leniusculus was imported, at least in two cases, from Sweden and Germany during the early and late 1980's respectively, in order to replace $A$. astacus stocks impoverished by human activities. Recently, Cherax quadricarinatus specimens have been seen in a restaurant's aquarium and pet shop, raising fears about uncontrolled imports of alien pet species. During our 2004-2005 survey, we found that $P$. leniusculus established not only a thriving population in the artificial Lake Agra (Region of Central Macedonia), but also they co-occur with $A$. torrentium there. It is also suspected that $A$. astacus may co-occur there with these two species, as three large male specimens of $A$. astacus were caught in a creek close to the lake. Concerning $A$. leptodactylus, there are three sets of preserved samples from the River Evros (state border with Turkey in Thrace today), dated back to the $19^{\text {th }}$ century, but no recent information about occurrence was available. But the accidental catch of six specimens of $A$. leptodactylus during May 2005 in that river re-documented the occurrence of the species. Finally, a deep-dwelling $A$. torrentium population with bluish legs was found to live in depths up to 7,800 meters inside the Aggitis Cave in northeastern Greece. There is a lot of work to be done on geographic distribution, population 
dynamics, genetics, reproduction, nutrition, diseases, and farming of crayfish species in Greece. Moreover, several actions should be undertaken to reform the existing legislation, in order to protect the native species and their habitats.

Key-words: crayfish, geographical distribution, indigenous, non-indigenous, mortality, Greece.

\section{RÉPARTITION GÉOGRAPHIQUE, MORTALITÉS RÉCENTES ET MESURES DE CONSERVATION DES ÉCREVISSES DANS LES EAUX DOUCES HELLÉNIQUES}

\section{RÉSUMÉ}

Les écrevisses se retrouvent dans 20 des 53 préfectures grecques et elles forment des populations isolées dans les eaux relativement peu influencées par les hommes. Trois espèces indigènes d'écrevisses (ICS) se reproduisent dans les eaux grecques: Astacus astacus, Astacus leptodactylus et Austropotamobius torrentium, et une espèce nonindigène (NICS) Pacifastacus leniusculus également. La Grèce représente probablement la répartition naturelle la plus méridionale au monde pour $A$. astacus et $A$. torrentium. Quant à la NICS, $P$. leniusculus, elle a été importée en Grèce au moins deux fois, respectivement de Suède et d'Allemagne au début et à la fin des années 80 du XXe siècle, afin de remplacer des stocks d'A. astacus appauvris par les activités humaines. Récemment, des spécimens de Cherax quadricarinatus ont été identifiés dans un aquarium d'un restaurant et dans celui d'un magasin d'animaux, provoquant des craintes au sujet des importations non-contrôlées des espèces étrangères. Au cours de nos observations 2004-2005, nous avons constaté que $P$. leniusculus a établi non seulement une population qui prospère dans le lac artificiel Agra (région de Macédoine centrale), mais également cette population coexiste avec $A$. torrentium. On suspecte également qu'A. astacus y soit présent avec ces deux espèces, car trois grands spécimens mâles d'A. astacus ont été attrapés dans un ruisseau près du lac. Pour ce qui concerne $A$. leptodactylus, il y a trois collections de spécimens préservés depuis le $\mathrm{XIX} \mathrm{X}^{\mathrm{e}}$ siècle, en provenance du fleuve Evros (frontière d'état avec la Turquie en Thrace aujourd'hui), mais aucune information récente sur sa présence n'était disponible. Mais, en 2005, une capture accidentelle de six spécimens dans le même fleuve permet d'indiquer que l'espèce y est toujours présente. En outre, une population d'A. torrentium avec les pattes bleuâtres, qui vit dans les zones profondes, s'est avérée vivre dans les profondeurs jusqu'à 7800 mètres à l'intérieur de la grotte d'Aggitis en Grèce nord-est. II y a encore beaucoup de travaux à réaliser en ce qui concerne la distribution géographique, la dynamique de population, la génétique, la reproduction, les maladies et l'élevage des différentes écrevisses en Grèce. D'ailleurs, plusieurs actions devraient être entreprises pour réformer la législation existante, afin de protéger les espèces indigènes et leurs habitats.

Mots-clés : écrevisses, répartition géographique, indigène, non-indigène, mortalité, Grèce.

\section{INTRODUCTION}

Crayfish are well-known animals in Europe and their association to humans goes quite far back. One of the oldest evidences for their importance to human affairs is the representation of a crayfish on a silver coin (drachma) dating at around 450-400 B.C. (Figure 1), that was minted by Apollonia Pontica, a Greek Miletian colony on the BlackSea coast (STANCOMB, 2000). Aristotle (384-322 B.C.) provides the earliest extant literary reference to crayfish as " $\alpha \sigma \tau \alpha \kappa o ́ s "$ (astakós) in his book "Historiae Animalium" (ARISTOTLE, H.A. 530 a 28). 

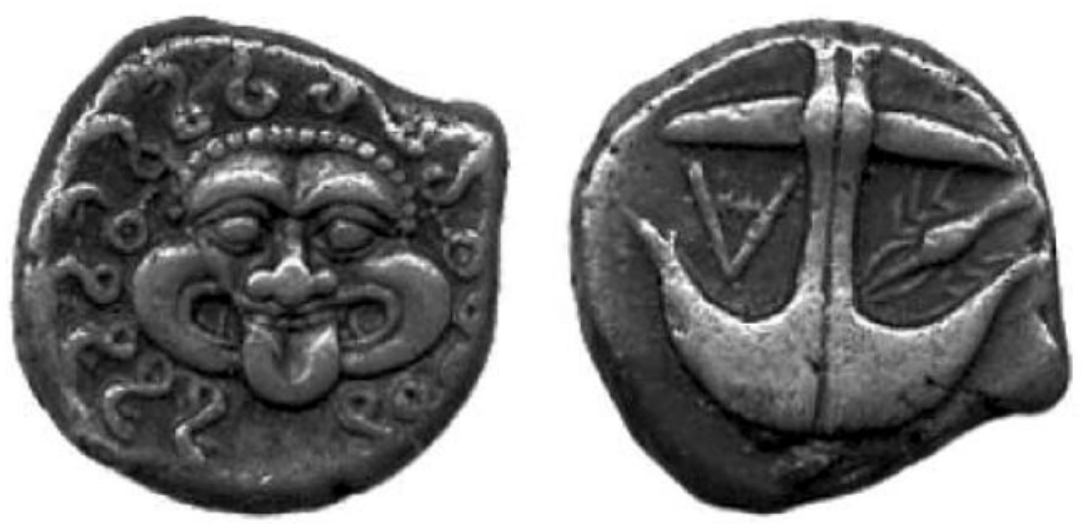

\section{Figure 1}

Greek silver coin (drachma minted between 450-400 B.C.) from Apollonia Pontica (Black Sea) with the picture of a crayfish on one side.

\section{Figure 1}

Pièce grecque en argent (drachme monnayée entre 450-400 B.C.) d'Apollonia Pontica (la Mer Noire) avec la figure d'une écrevisse sur un côté.

In the Medieval central Europe, crayfish were eaten already in the $13^{\text {th }}$ century. The catholic monks were among the firsts to start eating them. They were ideal substitute for meat during times of fasting, as they were considered as fish and thus permitted. Eventually, crayfish dishes were introduced to the Royal courts and novelties of Medieval central and northern Europe (SWAHN, 2004). Since then, people were involved in crayfish fishing and crayfish cooking all around Europe. Big towns were among large crayfish consumers such as Paris, which was probably the biggest consumer in the $19^{\text {th }}$ century (CARBONNIER, 1869), importing crayfish from Germany and the Netherlands, then from Poland and Ukraine, and then even from Russia and Finland (DROUIN DE BOUVILE, 1906; ANDRÉ and LAMY, 1935). However, the uncontrollable outbreaks of "crayfish plague" (Aphanomyces astaci Schickora, 1906) originally imported from North America (ALDERMAN, 1996), overfishing and industrial pollution led to dramatic decline of the stocks in most European countries. The remaining stocks were put under further pressure during the $20^{\text {th }}$ century, as a result of imports of non-indigenous crayfish species (NICS) from North America, especially Pacifastacus leniusculus (Dana, 1852) and Procambarus clarkii (Girard, 1852), which are potential competitors, as well as potential carriers of the crayfish plague (HOLDICH, 2003).

Greece, where today crayfish is called " $\kappa \alpha \rho \alpha \beta^{\prime} \delta \alpha$ " (karavída), is situated at the south-eastern edge of Europe over an area of $131,960 \mathrm{~km}^{2}$ with $20 \%$ of it divided among its 3,000 islands. The country has a three-tier administrative structure, based on 13 "General Regional Secretariats" ("the Regions"), 53 "Prefectural Authorities" ("the Prefectures") and the Municipalities. Concerning natural environment, numerous lakes and rivers provided refugia for crayfish in southern Balkans during the last glacial periods (ALBRECHT, 1983; SOUTY-GROSSET et al., 1997; HOLDICH, 2002). High mountains provided physical isolation for many aquatic animals (ECONOMIDIS and BANARESCU, 1991), suggesting the area as a "hot spot" for biodiversity. This is actually the situation in the region within the species Austropotamobius torrentium (Schrank, 1803), according to genetic data (TRONTELJ et al., 2005), as well as within Astacus astacus (Linnaeus, 1758) (KARAMAN, 1962, 1963; ALBRECHT, 1982) and Astacus leptodactylus Eschscholtz, 1823 (KARAMAN, 1963) according to morphological intraspecific "plasticity". 
Published work on crayfish distribution (both indigenous crayfish species ICS and non-indigenous crayfish species NICS) in Greece is very scarce. Moreover, unidentified and misidentified animals by some authors, made the situation even more complex. Previous papers on pan-European crayfish distribution (HOLDICH 1999, 2002, 2003; MACHINO \& HOLDICH, 2006) provide a description of crayfish distribution up to 1996, but in northern Greece only. A recent book on European crayfish (SOUTY-GROSSET et al., 2006) does not mention detailed information on the Greek ones either. Therefore, the present paper is the first attempt to review the crayfish distribution all over Greece, after having gathered data from literature search, collected specimens and questionnaires.

The present study aims to present both historical and current distribution of all crayfish species in Greece. Moreover, data regarding recent mortalities and conservation measures applied in Greece are presented. Finally, proposals are presented for future habitat and species conservation actions.

\section{MATERIALS AND METHODS}

Data (sampling of animals, information on distribution and habitats, etc.) were collected according to a protocol proposed by MACHINO and FÜREDER (2005), nevertheless, slight modification to the protocol was necessary for the present study. A questionnaire was also distributed to Fisheries Departments of the Prefectures and incoming information was put into an Excel database. Moreover, field observations and sample collections were made during 2004-2005 and new literature, which has not been readily available to astacologists in Western Europe, was used in order to update the general distribution of crayfish in Greece. Collected specimens were identified according to the determination key of FÜREDER and MACHINO (2002).

Crayfish distribution maps have not been published for Greece up to now. The distribution map presented by MACHINO and FÜREDER (2005) for A. torrentium, refers only to a broad European context. A distribution map of $P$. leniusculus by LEWIS (2002) is based on previous published data and highlights with shaded area the unsuccessful introduction of the species in the River Kalamas (north-western Greece). But LEWIS' large-scale map is rather "crude" and does not include the recently documented satellite population of Lake Agras in northern Greece. Moreover, a map for $A$. astacus included in THEOCHARIS (1986) work is limited only to the Region of Epirus. Therefore for the present study, spot distribution map for every species is produced together with previously known and recently available data. In the distribution maps "historical record" does not necessarily mean an extinction of the species. It indicates indeed extinction or simply no recent data available. Finally the existing national legislation is reviewed.

\section{RESULTS AND DISCUSSION}

\section{General view}

Crayfish distribution at the regional and prefectural level in Greece is shown in Table I and Figure 2. Crayfish distribution extends to 20 out of the 53 Prefectures (38\%) and to 6 out of the 13 Regions (46\%) of the country. Particularly, A. astacus can be found in 11 prefectures (in 6 regions), $A$. torrentium in 13 prefectures (in 3 regions) and $A$. leptodactylus and $P$. leniusculus in 1 prefecture (1 region), respectively (see Table I for details).

Available literature for each crayfish species found in Greece is shown in Table II with corresponding river, lake system, city or mountain area after distribution analysis. 


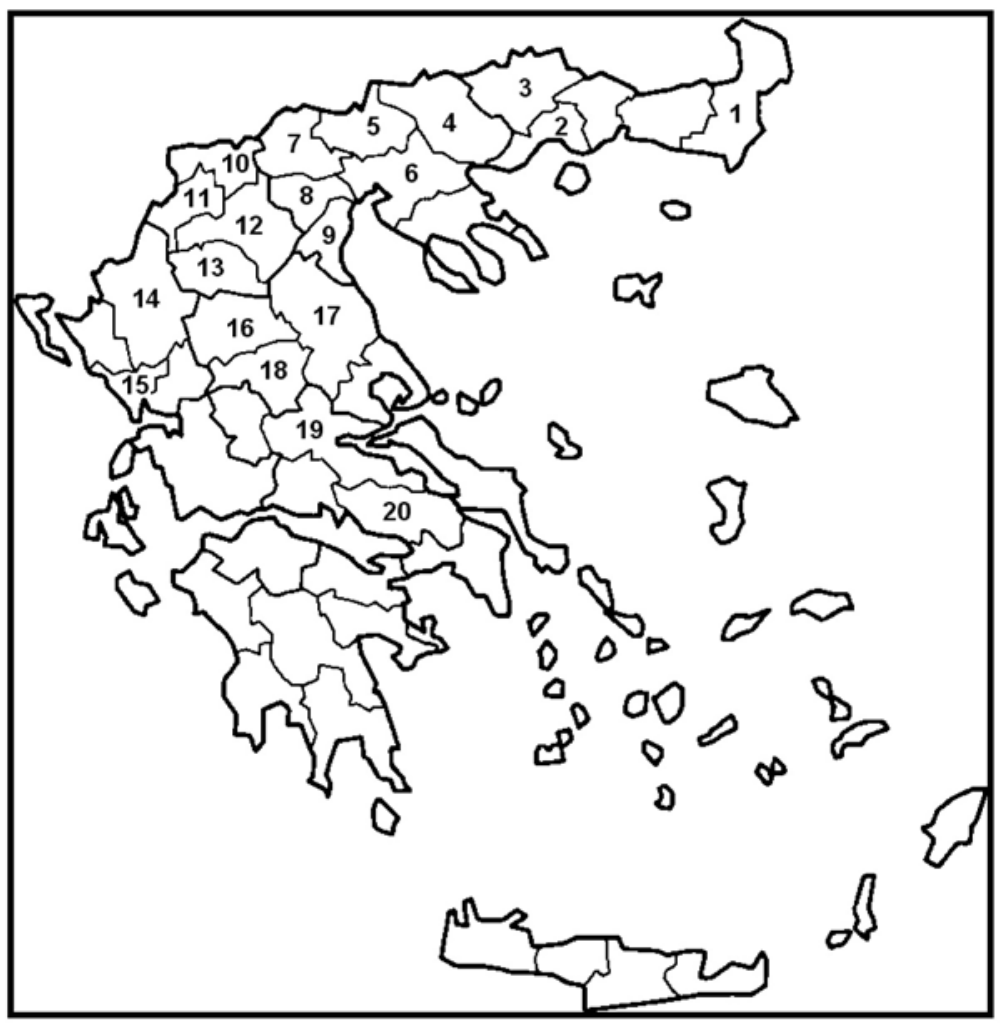

Figure 2

Map of the prefectures in Greece with known occurrence of crayfish. Numbers correspond to the prefectures given in Table $\mathrm{I}$.

Figure 2

Carte des préfectures en Grèce avec la présence d'écrevisses connue. Les nombres correspondent aux préfectures données au Tableau I.

Three native freshwater crayfish species have been found in Greece so far: Astacus astacus, Astacus leptodactylus and Austropotamobius torrentium. Moreover, Pacifastacus leniusculus juveniles were introduced at least in two places in the early and late 1980's, but its presence has been documented only in the artificial Lake Agra, near Edessa (Region of Central Macedonia) (Table I). Recently, a male Cherax quadricarinatus (von Martens, 1868) was seen in a restaurant's aquarium (city of Igoumenitsa, Region of Epirus). On a subsequent visit to the nearby aquarist trading shop, three more $C$. quadricarinatus were available to the aquarium hobbyists (PERDIKARIS et al., 2005c). There is an increasing interest for $C$. quadricarinatus aquaculture and aquarium trade in the country. The species has the potential to survive through the Greek winter conditions; however, there is still no evidence of escape and invasion of the local catchments.

\section{Astacus astacus}

Astacus astacus is very widespread in the north-western and central parts of Greece (Regions of Epirus and Thessaly, mainly in the Kalamas and Pinios drainage systems, respectively) (Figure 3). Also its distribution extends to the north in the Region of Central Macedonia and to the western part of the Region of East Macedonia and Thrace. Its most southern distribution limit seems to be the River Kifissos in Viotia Prefecture (Region of Sterea Ellada) (KASTRITSI-KATHARIOU and SKEPARIOTI 1990; KASTRITSI-KATHARIOU et al. 1994). 


\section{Table I}

Crayfish species distribution at the regional and prefectural level in Greece (also former occurrence included). Numbers in the "Prefectures" column indicate location of the prefectures as shown in Figure 2. Abbreviations: ? = presence of non-identified crayfish based on information provided by local people and Fisheries Departments, or possible/suspected presence, $\mathrm{PBL}=$ presence based on published sources, SMPL = presence of species identified by the authors, INTRO = species introduced but presence not certified.

\section{Tableau I}

Répartition des espèces d'écrevisses au niveau régional et préfectoral en Grèce (y compris ancienne présence). Les chiffres dans la colonne "Préfectures" indiquent la localisation des préfectures, représentées sur le Figure 2. Abréviations : ? = présence d'écrevisses non identifiées d'après les informations fournies par des locaux et par les départements de pêche locaux, ou présence possible/suspectée, $\mathrm{PBL}=$ présence basée sur des sources publiées, SMPL = présence des espèces identifiées par les auteurs, INTRO = espèce introduite mais présence non constatée.

\begin{tabular}{|c|c|c|c|c|c|}
\hline Regions & Prefectures & $\begin{array}{c}A . \\
\text { astacus }\end{array}$ & $\begin{array}{c}A . \\
\text { torrentium }\end{array}$ & $\begin{array}{c}\text { A. } \\
\text { leptodactylus }\end{array}$ & $\begin{array}{c}P . \\
\text { leniusculus }\end{array}$ \\
\hline \multirow{4}{*}{$\begin{array}{l}\text { East Macedonia } \\
\text { and Thrace }\end{array}$} & Evros (1) & & & PBL, SMPL & \\
\hline & Kavala (2) & & SMPL & & \\
\hline & Drama (3) & & PBL, SMPL & & \\
\hline & Serres (4) & $\mathrm{PBL}$ & PBL, SMPL & & \\
\hline \multirow{5}{*}{ Central Macedonia } & Kilkis (5) & PBL & PBL, SMPL & & \\
\hline & Thessaloniki (6) & & PBL & & \\
\hline & Pella (7) & PBL, SMPL & PBL, SMPL & & PBL, SMPL \\
\hline & Imathia (8) & & PBL, SMPL & & \\
\hline & Pieria (9) & & PBL & & \\
\hline \multirow{4}{*}{ West Macedonia } & Florina (10) & $?$ & $?$ & & \\
\hline & Kastoria (11) & & SMPL & & \\
\hline & Kozani (12) & & $?$ & & \\
\hline & Grevena (13) & & $?$ & & \\
\hline \multirow{2}{*}{ Epirus } & Ioannina (14) & PBL, SMPL & & & INTRO \\
\hline & Preveza (15) & PBL & & & \\
\hline \multirow{3}{*}{ Thessaly } & Trikala (16) & $?$ & & & \\
\hline & Larisa (17) & PBL & PBL & INTRO & \\
\hline & Karditsa (18) & PBL & & & \\
\hline \multirow{2}{*}{ Sterea Ellada } & Fthiotida (19) & SMPL & & & \\
\hline & Viotia (20) & PBL & & & \\
\hline
\end{tabular}




\section{Table II}

Available literature for each crayfish species found in Greece, categorized according to river and lake system, city or mountain area. Areas are categorised according to their geographical distribution starting from north-east.

\section{Tableau II}

Littérature disponible pour chaque espèce d'écrevisse trouvée en Grèce, classée selon le système lacustre ou de rivière, la ville ou le secteur de montagne. Les secteurs sont classés selon leur répartition géographique à partir du nord-est.

\begin{tabular}{|c|c|c|c|c|}
\hline & $\begin{array}{c}A . \\
\text { astacus }\end{array}$ & $\begin{array}{c}A . \\
\text { leptodactylus }\end{array}$ & $\begin{array}{c}A . \\
\text { torrentium }\end{array}$ & $\begin{array}{l}P . \\
\text { leniusculus }\end{array}$ \\
\hline River Evros and tributaries & & $3,21,24$ & & \\
\hline $\begin{array}{l}\text { River Nestos (tributaries) and Kato } \\
\text { Nevrokopi }\end{array}$ & & & 24 & \\
\hline Ano Kefalari Dramas & & & 22 & \\
\hline River Aggitis \& Cave Aggitis & & & $\begin{array}{l}15,18,19, \\
22\end{array}$ & \\
\hline Aggistro Serron & & & $10,22,24$ & \\
\hline $\begin{array}{l}\text { Akritochori and Karidochori } \\
\text { (tributaries of Strymon River) }\end{array}$ & & & 22,24 & \\
\hline Lake Doirani & 1,3 & & & \\
\hline Thessaloniki suburbs & & & 4 & \\
\hline River Axios and tributaries & $1,3,6,7$ & & 22,24 & \\
\hline Nisi-Edessa & & & 24 & \\
\hline Artificial Lake Agra & 13,14 & & & 13,14 \\
\hline $\begin{array}{l}\text { Rodochori (Naousa-Vermio } \\
\text { mountain) }\end{array}$ & & & 4,7 & \\
\hline River Kalamas & $\begin{array}{l}8,13,16 \\
17,20,24\end{array}$ & & & \\
\hline River Kalamas (introduced) & & & & 8 \\
\hline Lake Pamvotis & $\begin{array}{l}2,3,7,8 \\
12,13\end{array}$ & & & \\
\hline River Louros & 8,20 & & & \\
\hline $\begin{array}{l}\text { Aoos-Voidomatis River system } \\
\text { and artificial Lake of Aoos springs }\end{array}$ & $\begin{array}{l}8,16,20 \\
24\end{array}$ & & & \\
\hline Lake Vegoritida & 5 & & & \\
\hline Artificial Lake Plastira & 23 & & & \\
\hline River Pinios & 24 & & & \\
\hline $\begin{array}{l}\text { Litochoro (Olympos mountain) } \\
\text { and Daphni spring (Pinios) }\end{array}$ & & & 7 & \\
\hline Lake Argyropouliou-Mati Tyrnavou & 2 & & & \\
\hline River Kifissos and Lake Yliki & 9,11 & & & \\
\hline
\end{tabular}

1: BALSS (1928); 2: ATHANASSOPOULOS (1935); 3: KARAMAN (1963); 4: BOTT (1972); 5: KOYKOYRA (1973); 6: ALBRECHT (1982); 7: KINZELBACH (1986); 8: THEOCHARIS (1986); 9: KASTRITSI-KATHARIOU and SKEPARIOTI (1990); 10: NEOPHYTOU et al. (1993); 11: KASTRITSI-KATHARIOU et al. (1994); 12: PASCHOS and KAGALOU (1995); 13: KEVREKIDIS et al. (1999); 14: EVAGGELIDIS (2001); 15: KOUTRAKIS et al. (2003); 16: NIKOLAOU (2004); 17: SAVVIDIS (2005a, b); 18: KOUTRAKIS et al. (2005a); 19: KOUTRAKIS et al. (2005b); 20: PERDIKARIS et al. (2005a); 21: PERDIKARIS et al. (2005b); 22: TRONTELJ et al. (2005); 23: KIOUSIS (2006); 24: MACHINO and HOLDICH (2006). 


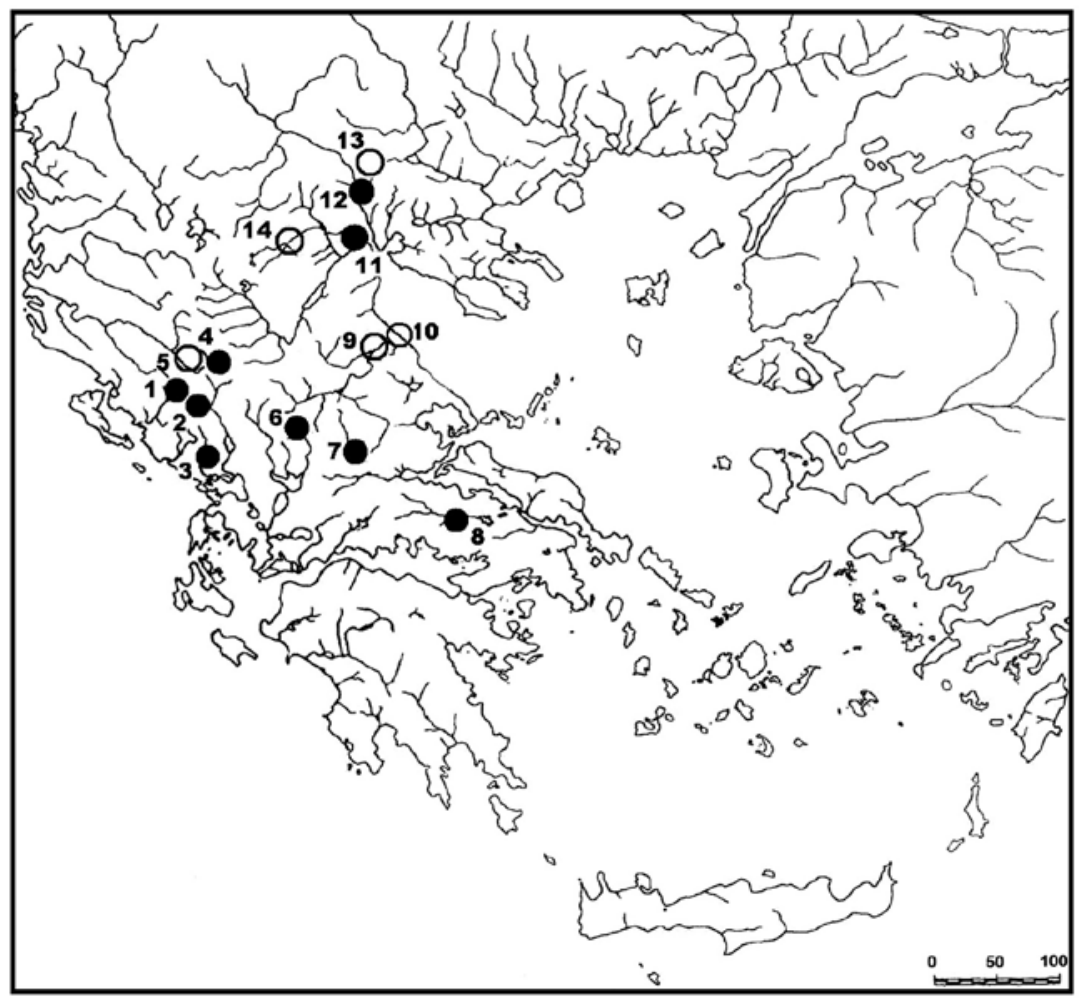

Figure 3

Distribution map of $A$. astacus and the hydrographic network of Greece (background modified from ECONOMIDIS, 1995) (black circle: confirmed presence, open circle: historical record). 1. River Kalamas, 2. Lake Pamvotis, 3. River Louros, 4. Artificial Lake of River Aoos springs and its tributaries, 5. River Voidomatis (Kipi), 6. Artificial Lake of Plastiras, 7. Creek Bougazi \& Lake Xyniada, 8. River Kifissos and Lake Yliki, 9. Lake Argyropouliou (= Mati Tyrnavou), 10. River Pinios (Tembi valley), 11. Creek Melisiotikos (tributary of Loudias), 12. Tributaries of the Axios, 13. Lake Doirani, 14. Lake Vegoritida.

Figure 3

Carte de distribution d'A. astacus et le réseau hydrographique de Grèce (fond modifié d'ECONOMIDIS, 1995) (cercle noir : présence confirmée, cercle blanc: présence historique). 1. Rivière Kalamas, 2. Lac Pamvotis, 3. Rivière Louros, 4. Lac artificiel des sources d'Aoos et ses affluents, 5. Rivière Voidomatis (Kipi), 6. Lac artificiel de Plastiras, 7. Ruisseau Bougazi et lac Xyniada, 8. Rivière Kifissos et lac Yliki, 9. Lac Argyropouliou (= Mati Tyrnavou), 10. Fleuve Pinios (vallée de Tembi), 11. Ruisseau Melisiotikos (affluent du Loudias), 12. Affluents de l'Axios, 13. Lac Doirani, 14. Lac Vegoritida.

Species distribution is much more restricted today than in previous decades, and is now resulting in isolated populations, since crayfish populations have been confined to the upper river segments and pristine lentic environments. The decline is probably attributed to the crayfish plague and to the anthropogenic impacts (degradation or destruction of crayfish habitats and reproductive and nursery grounds, dam construction and alteration of hydrodynamic patterns of rivers, pollution, overfishing, etc.), but no official studies have been carried out. Nevertheless, there are indications that some populations are recovering 
during the recent years (i.e. reappearance of crayfish in few places in the Region of Thessaly without any restocking support).

There were efforts to reintroduce the species in various rivers and streams, not always with success. Restocking efforts to re-establish $A$. astacus population in the Louros River (Kerasonas area) were rather unsuccessful (in 1989, 1990, 1995 and 2001, 200, 1,000, 500 and 200 individuals were released respectively) (Perdikaris, unpub. data). On the other hand, into the River Kalamas, where a re-introduction was carried out during the 1980's with $A$. astacus (150 kg of juveniles; Perdikaris, unpub. data) from Larissa (River Pinios drainage) (Théocharis, pers. com.), there is a healthy crayfish population today (NIKOLAOU, 2004; PERDIKARIS et al., 2005a; MACHINO and HOLDICH, 2006). Furthermore, 100 specimens from the River Kalamas were released into Lake Pamvotis (= Lake loannina) during 2004, but the highly eutrophication of the lake is probably hostile for crayfish (Perdikaris, unpub. data). Finally, into Lake Agra, after the depletion of the local population, there were yearly re-introductions, during 1988-1992, with specimens from Orhomenos (Viotia) and with specimens hatched in the Edessa Aquaculture Station (Paleokostas, pers. com.). Still the presence of the species in the lake today is under question.

Crayfish commercial fishing in Greece takes place today only in the artificial lake of Aoos River and in the River Kalamas (Parakalamos), where the catches ranged from $6 \mathrm{t}$ (2004) to $20 \mathrm{t}$ (2002). Commercial fishing activity has been re-established in the River Kalamas after successful restocking with $A$. astacus from Larissa (River Pinios drainage) and recent estimates are close to $200 \mathrm{~kg}$ per week (although illegally trapped mostly), according to data gathered from local fishermen (Perdikaris, unpub. data). Moreover, local environmental protection society organises annual crayfish festivals in the village Parakalamos, where up to $600 \mathrm{~kg}$ of $A$. astacus are consumed every August. In most cases, crayfish populations are not exploited on a commercial basis, as Greek consumers are practically not so familiar with this source of animal protein. In some cases, crayfish are considered as by-catch and simply returned back to the river (i.e. A. leptodactylus in the River Evros: see below) or they are consumed locally (i.e. A. torrentium near the city of Drama: see below). Crayfish are available in low quantities in some fish markets, mainly during the fasting period before Easter. In some places, with established tradition in crayfish catching, crayfish have been included in the local cuisine and served as delicatessen in specialised restaurants (i.e. city of loannina in the Region of Epirus). Official production and export figures are not available, although considerable amounts of live cargo (presumably A. astacus) had been exported to France during 1988 and 1989 and 57 tons of live $A$. astacus exported to Sweden at least during 1990 (cited in HOLDICH and WHISSON, 2004) and the early 1990's (see next paragraph).

Efforts have been also made for hatching of the species, mainly for re-introduction or farming purposes (i.e. Edessa Aquaculture Station, Louros Aquaculture Station in Terovo). In the future, from the point of view of native crayfish conservation, introduction of $A$. astacus may be problematic if strains of non-Greek origins are stocked into natural waters. A. astacus in Greece is considered Astacus astacus balcanicus, while in central Europe it is Astacus astacus astacus (KARAMAN, 1963; ALBRECHT, 1982). A. a. balcanicus is believed to occur only in Greece, Albania and the F.Y.R.O.M. (Former Yugoslavian Republic of Macedonia). Exportation of living A. astacus from Greece can also be problematic if specimens are released in nature (there is at least one recorded exportation of 90 tons of crayfish from Greece and former Yugoslavia to France in 1990; KEVREKIDIS et al., 1999). Attention should be given also to the strains of crayfish that will be used for farming (for re-introduction or exportation purposes).

Current research in western Greece (Dept Aquaculture \& Fisheries, Technological Educational Institute of Epirus) is focusing on the biology and hatching of the species. 


\section{Astacus leptodactylus}

Astacus leptodactylus has not been reported in Greece for a long time. Bibliographical sources on geographical distribution of $A$. leptodactylus are extremely scarce. KARAMAN (1963) referred to the species occurrence in the River Evros after having observed several museum collections. Also MACHINO and HOLDICH (2006) gathered information about the Greek specimens conserved by the Naturhistorisches Museum in Wien dating back to 1893 (inventories No 3090, 3093 and 2873). However, KALLISTORATOS (1990) and WESTMAN et al. (1990) listed the species as introduced, probably not knowing the presence of the Greek specimens conserved in the museum. Recent findings confirm the occurrence of the species in the River Evros, close to the city of Didimotiho (Figure 4). Six specimens were caught in traps in this area by local fishermen on May 2005 and identified as A. leptodactylus (PERDIKARIS et al., 2005b; PERDIKARIS et al., 2007). Crayfish are not regarded as target species by local fishermen and they are caught accidentally in traps placed for fish near the river bank.

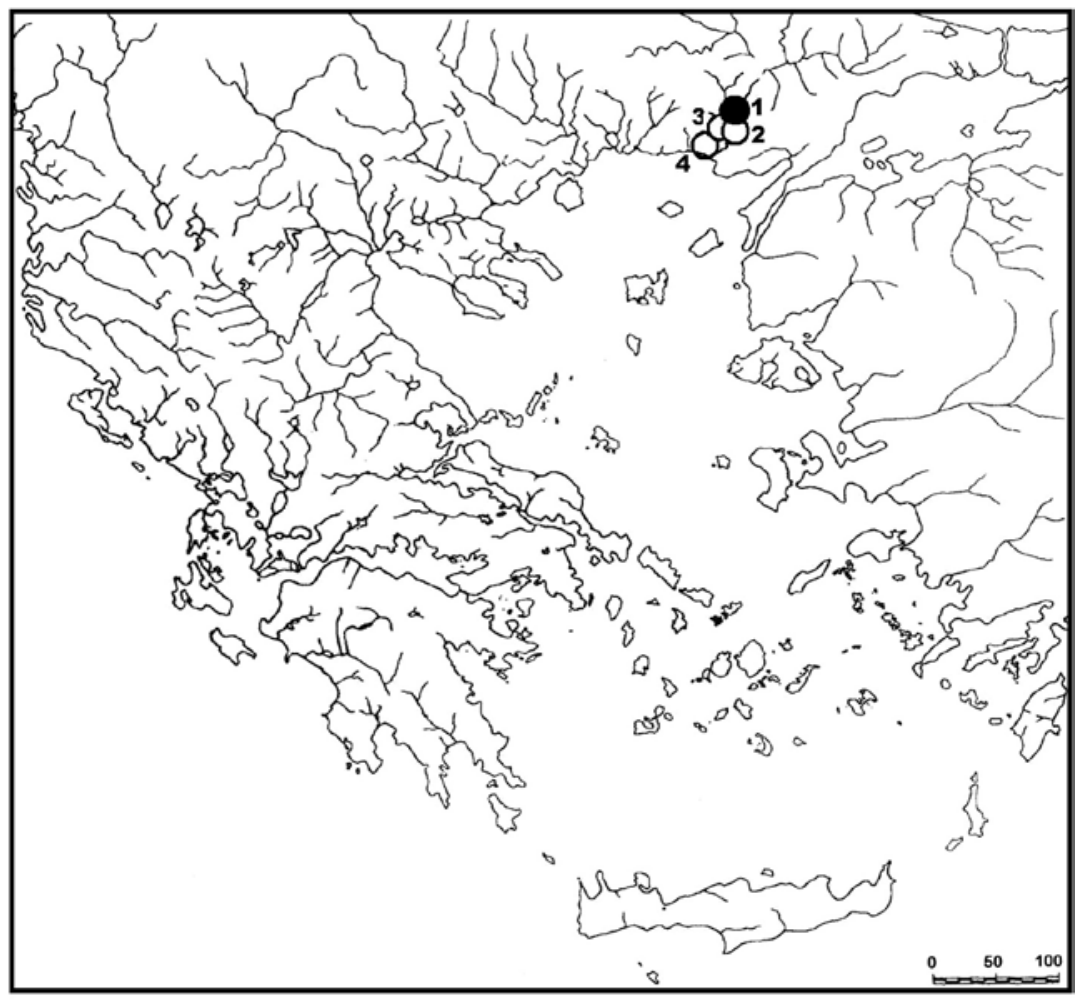

Figure 4

Distribution map of $A$. leptodactylus and the hydrographic network of Greece (background modified from ECONOMIDIS, 1995) (black circle: confirmed presence, open circle: historical record) 1. Didimotoiho, 2. Soufli, 3. Mandra, 4. Alexandroupoli.

\section{Figure 4}

Carte de distribution d'A. leptodactylus et le réseau hydrographique de Grèce (fond modifié d'ECONOMIDIS, 1995) (cercle noir : présence confirmée, cercle blanc: présence historique) 1. Didimotoiho, 2. Soufli, 3. Mandra, 4. Alexandroupoli. 
Also some populations of undetermined crayfish have been located in other sites in the neighbouring areas (PERDIKARIS et al., 2007), and the vicinity of the places strongly suggests that these populations probably belong to the same species (A. leptodactylus).

These findings make necessary the organisation of a more intensive research in the Greek Evros River drainage. Finally there are information that specimens of the species were introduced in the Pinios drainage during the 1980's, but there is no indication of species existence in the area today (Paleokostas, pers. comm.).

\section{Austropotamobius torrentium}

Distribution of Austropotamobius torrentium is localised in the centre of northern Greece, Regions of East Macedonia and Thrace, Central Macedonia, West Macedonia and Thessaly, i.e. in the drainage systems of the Nestos, Strymon, Axios, Aliakmon and Pinios Rivers (Figure 5). The Greek parts of the Evros River drainage cannot be excluded, as it is present in the Bulgarian part (BULGURKOV, 1961; SUBCHEV and STANIMIROVA, 1998) and recently the species was found in European Turkey (TRONTELJ et al., 2005; HARLIOGLU and GÜNER, 2006), but no findings have ever been reported from the Greek Evros drainage. The most western distribution limit documented by recently-caught specimens seems to be the area around the city of Kastoria, close to the Albanian borders.

In Greece, abundance of $A$. torrentium is today much lower than in previous decades. The decline is attributed mainly to the destruction and damaging of the crayfish habitat. Such one sad case was observed in a carstic river near Nevrokopi, where a road construction severely damaged the habitat in 1996 (Machino, unpub. data). Nevertheless, there are indications that some populations in Greece are recovering during the recent years. The species is locally consumed by people, i.e. around the town of Drama (Machino, unpub. data).

Although A. torrentium is widespread in central and south-eastern Europe, it has not been recorded living deep inside caves before. Recently it has been recorded from a variety of depths inside the Aggitis Cave in northern Greece (KOUTRAKIS et al., 2005a) and efforts were made to study the growth of the juveniles that were hatched from specimens coming from the broader area of the cave (KOUTRAKIS et al., 2005b). The crayfish have been found in the outflowing River Aggitis, in the entrance to the cave, as well deep inside the cave at 2,100 $\mathrm{m}$ and 7,100 $\mathrm{m}$ from the entrance. The discovered crayfish had normal pigmentation in general, but those from the deeper parts had characteristically bluish pereopods. The finding of crayfish so deep inside a cave system is unusual, and is probably the deepest record so far in Europe and North America. The origin of the deepdwelling crayfish is unknown. Although $A$. torrentium also occur above the cave system, it is unlikely that the crayfish could have entered the system from there in recent times because of sedimentation blocking the cave entrance, but they may have become trapped in the cave prior to this event. Alternatively, they may have moved upstream into the cave system from the Aggitis River over time. Research is continuing in order to determine whether they complete the whole of their life history in the cave system and what they are feeding on.

\section{Pacifastacus leniusculus}

Pacifastacus leniusculus was introduced in the 1980's, in selected areas where the native crayfish populations were diminished. Approximately 1,000 juveniles were imported from a Swedish hatchery (Simontorp Aquaculture AB) in July 1982, in order to be released into the River Kalamas in western Greece (THEOCHARIS, 1986). According to Paschos (pers. comm.) all juveniles died within one week after being released into small net enclosure in the River Kalamas. During 1987 another 2,200 specimens (of $7 \mathrm{~cm}$ TL each) were imported from Germany and introduced into the same river, but today the species presence is doubtful (Paschos, pers. comm.). 


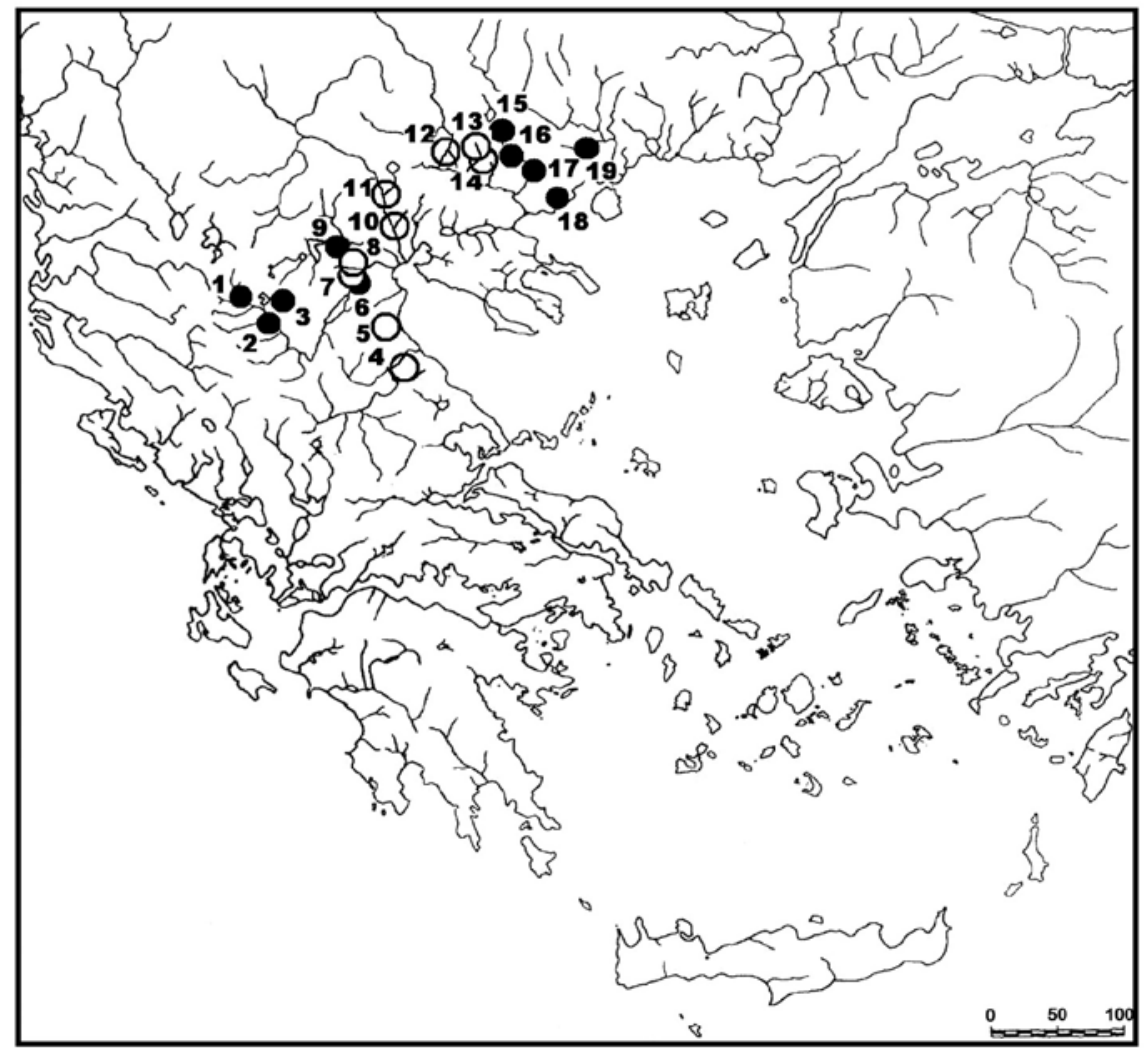

Figure 5

Distribution map of $A$. torrentium and the hydrographic network of Greece (background modified from ECONOMIDIS, 1995) (black circle: confirmed presence, open circle: historical record). 1. Koromilia Creek (tributary of the River Aliakmonas, Kastoria), 2. Vogatsiko Creek (tributary of the River Aliakmonas, Kastoria), 3. Germas Creek (tributary of the River Aliakmonas, Kastoria), 4. Dafni Spring (Tembi Valley), 5. Litochoro, 6. Rachia Creek (tributary of the River Aliakmonas, Veroia), 7. Vermio Mountain, 8. Rodochori near Naousa, 9. Artificial Lake Agras, 10. Thessaloniki suburbs, 11. Tributaries of the River Axios, 12. Acritochori, 13. Aggistro, 14. Karidochori, 15. Vathytopos-Katafyto, 16. Aggitis Cave (River Aggitis), 17. River Aggitis and its tributaries, 18. Mesoropi, 19. Paradisos Spring.

Figure 5

Carte de distribution d'A. torrentium et le réseau hydrographique de Grèce (fond modifié d'ECONOMIDIS, 1995) (cercle noir : présence confirmée, cercle blanc : présence historique). 1. Ruisseau Koromilia (affluent de l'Aliakmonas, Kastoria), 2. Ruisseau Vogatsiko (affluent de l'Aliakmonas, Kastoria), 3. Ruisseau Germas (affluente de I'Aliakmonas, Kastoria), 4. Fontaine de Dafni (vallée de Tembi), 5. Litochoro, 6. Ruisseau Rachia (affluent de l'Aliakmonas, Veroia), 7. Montagne Vermio, 8. Rodochori près de Naousa, 9. Lac artificiel Agras, 10. Banlieues de Thessaloniki, 11. Affluents du fleuve Axios, 12. Acritochori, 13. Aggistro, 14. Karidochori, 15. Vathytopos-Katafyto, 16. Grotte d'Aggitis (rivière Aggitis), 17. Rivière Aggitis et ses affluents, 18. Mesoropi, 19. Fontaine de Paradisos. 
P. leniusculus was also introduced into Lake Agra, near Edessa (Pella Prefecture) in 1987 (1,800 specimens of $7 \mathrm{~cm}$ TL, imported from Germany; Paleokostas, pers. comm.), after a mass mortality incidence in the lake during 1976-1977 (EVAGGELIDIS, 2001). This is the only known-established population of the species in Greece (Figure 6). Interestingly, $P$. leniusculus co-occurs with the native $A$. torrentium in Lake Agra. Previously, it was reported (KEVREKIDIS et al., 1999; EVAGGELIDIS, 2001) that $P$. leniusculus co-occurred there with $A$. astacus, but recently-identified $A$. torrentium specimen from the lake put into question the presence of $A$. astacus. But also co-occurrence of all these three species in the lake cannot be excluded as well because three large male specimens of $A$. astacus were caught in a creek close to the lake (N.B. A. astacus was re-introduced into the lake during 1988-1992). Nevertheless a recent finding of a specimen, identified as $A$. astacus, from a stream close to the city of Gianitsa makes the Pella Prefecture, the only prefecture where all the above three species exist in Greece.

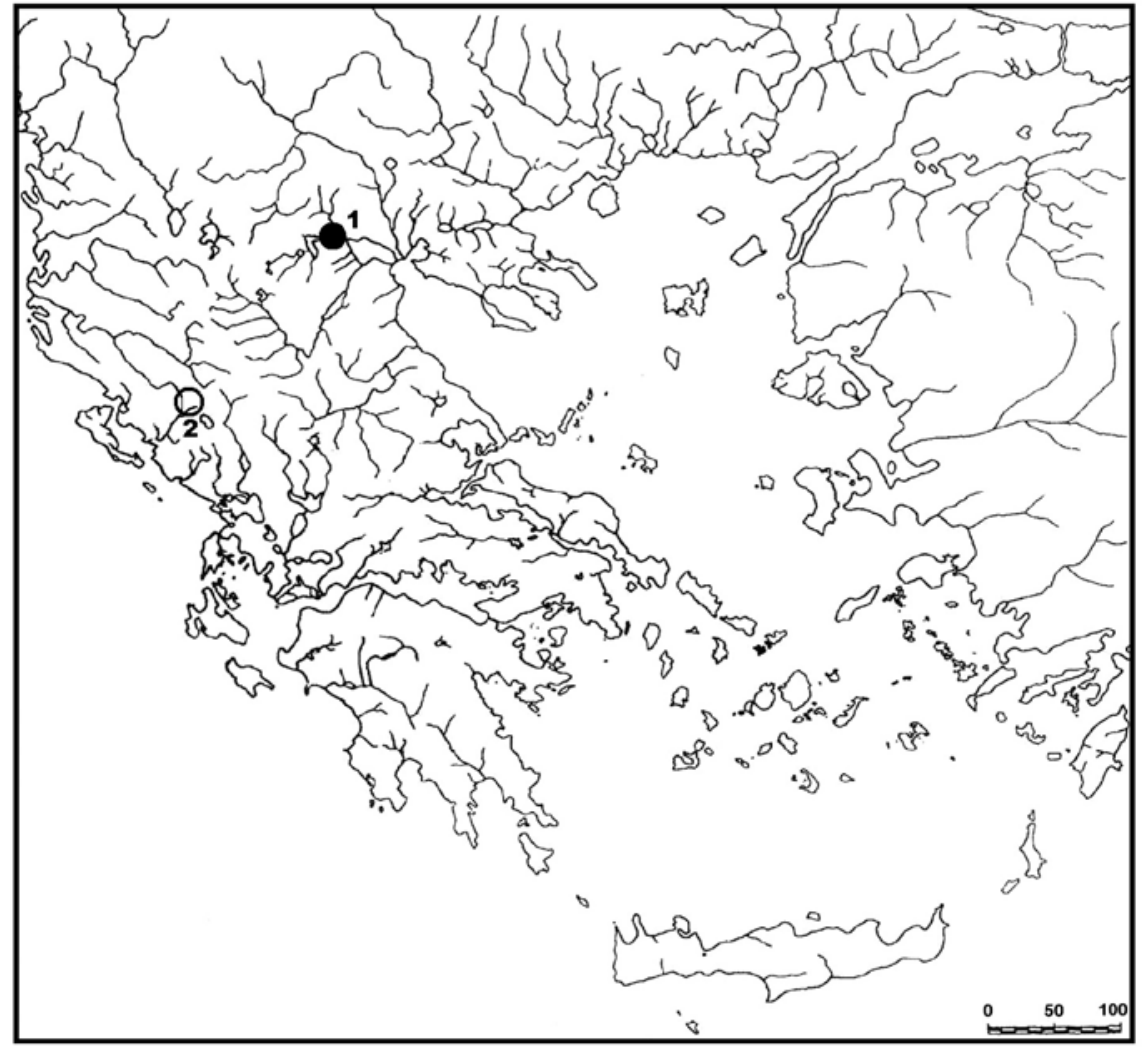

\section{Figure 6}

Distribution map of $P$. leniusculus and the hydrographic network of Greece (background modified from Economidis, 1995) (black circle: confirmed presence, open circle: historical record). 1. Artificial Lake Agras, 2. Tributary of the River Kalamas.

\section{Figure 6}

Carte de distribution de $P$. leniusculus et le réseau hydrographique de Grèce (fond modifié d'ECONOMIDIS, 1995) (cercle noir : présence confirmée, cercle blanc: présence historique). 1. Lac artificiel Agras, 2. Affluent de la rivière Kalamas. 


\section{Recent mortalities, diseases}

The crayfish plague (Aphanomyces astaci Schikora, 1906) had a severe impact on the crayfish populations in Greece. It was first reported on August 1982 to affect the A. astacus population in the River Kalamas, north-western Greece (THEOCHARIS, 1986; LOWERY and HOLDICH, 1988; ALDERMAN, 1996). This incident took place probably after the introduction (1982) of $P$. leniusculus juveniles from Sweden (LAURENT, 1997) and wiped out almost the entire $A$. astacus population in the area. The next year (1983), the plague affected the $A$. astacus population of the River Louros (THEOCHARIS, 1986). During 1996, when the area (Lake Pamvotis and Louros River) was visited by one of us (YM), no $A$. astacus was found (MACHINO and HOLDICH, 2006).

The last mass mortality of crayfish with thousands of dead and moribund animals occurred in August 2005 in a population of A. astacus in the main stream of the River Kalamas and its tributaries Gormos and Limbousdas (Region of Epirus, north-western Greece) (SAVVIDIS, 2005a; 2005b). It lasted 10-15 days and the mortality expanded along the river in a distance of approximately $15 \mathrm{~km}$. The fungus strain which was isolated by using RGY medium (Alderman D.J. pers. comm.; OIE Diagnostic Manual, 2000) had the following characteristics: colourless colonies, growth entirely within the agar and aseptate hyphae with rounded ends. The strain was sent to O.I.E. (Office International des Épizooties) crayfish plague reference laboratory CEFAS (Centre for Environment, Fisheries \& Aquaculture Science, Weymouth, U.K.) and the PCR result was negative. Diagnostically, however, the whole case remains suspicious for crayfish plague by taking into account the following important points:

- from the beginning and during the whole period of mass mortality, all the other animals in the same water bodies had been left unharmed,

- the case had progressive spreading (it lasted about two weeks),

- diseased crayfish seemed having paralytic behaviour; in some of them the carapace was fragile at slight pressing with the fingers,

- the results of toxicological (water and crayfish) and physicochemical (water) examinations were negative or in the frame of acceptable limits respectively,

- the isolation of the plague causative agent is usually very difficult.

However, the fact that previous and recent crayfish mass mortalities took place during summer months, when water flow level is low and agricultural activities and water demands for irrigation are increased, may also raise questions about possible environmental and/or toxicological impacts not yet considered. For example, standard procedures for corn farming in the area include the use of various pesticides and controlled flooding of the fields. High concentrations of pesticides (herbicides) have been detected during the summer months in the River Kalamas (LAMBROPOULOU et al. 2002). A case of considerably smaller scale losses was observed in limited part of the same area, in July 2004.

Based on clinical appearance of individuals caught during winter 2004, "burn spot" disease and "porcelain" disease have not yet affected $A$. astacus in the River Kalamas. However, epi-commensal organisms (Branchiobdellids) were present in high numbers in specimens from the same population (PERDIKARIS, unpub. data).

\section{Existing legislation and conservation measures, crayfish conservation sites}

Crayfish species are protected in Greece mainly by the EU Habitats Directive 92/43/EEC for the conservation of natural habitats and of wild fauna and flora (21.5.1992) (EE L 206 pag. 7, 22.7.92) (A. astacus in Annex V and A. torrentium in Annex II), ratified 
by the Greek legislation with the Common Ministerial Agreement 33318/3028/28.12.98, FEK 1289 B') and also by the Bern Convention (1979), which is ratified by the Greek legislation with the law 1335/1983 (FEK 32/A). Greek legislation forbids crayfish fishing from $15^{\text {th }}$ of February to $15^{\text {th }}$ of May and establishes a minimum size for fishing crayfish to $10 \mathrm{~cm}$ total length (Royal Decree 142/71, FEK 49A/71). In the River Kalamas, crayfish fishing is allowed only by using single-hook, according to Presidential Decree 1359/81 (FEK 338A/29.12.1981). In the artificial Lake of River Aoos, sport fishing is allowed only with specific permit, according to Number 3054/20-3-1996 decision of loannina Prefecture and only for $2 \mathrm{~kg}$ of crayfish per fisherman per day.

Concerning imports of alien crayfish species, there is a certain legal process of gaining import permission (No 147703/4.7.2002 Ministerial Act). This process is centrally controlled by the Ministry of Agricultural Development \& Food, via a specific commission.

It should be noted that the three-month closing period during springtime is inadequate to protect crayfish during egg carrying and hatching. Crayfish need to be protected during the whole reproductive cycle, covering the periods between mating and young-larvae carrying seasons (October to June). Moreover, important crayfish habitats need to be identified and protected, as Species Protection Areas (SPAs), according to article 22 of Appendix II of the EC Directive 92/43/EEC. Here the protection areas do not necessarily mean a total ban of crayfish catch. Crayfish fishing nevertheless should be carefully controlled and managed in order to keep the fishing pressure as low as possible while people can exploit these valuable animals. Finally, the new Water Framework Directive 2000/60EC requires the use of biota and especially macro-invertebrates in integrated freshwater quality assessment (ARTEMIADOU and LAZARIDOU, 2005). Therefore, the presence of crayfish may be used as a powerful indicator of surface water quality.

\section{CONCLUSIONS}

Available data on crayfish species occurrence, their habitats and distribution in Greece were until recently scattered in the literature and in many cases extremely scarce. The present work is an effort to gather and present all available data (both from past and recent literature and from samplings). Crayfish populations of $A$. astacus occur in north-west, north and central parts of the country (Regions of Epirus, Central Macedonia, Thessaly and Sterea Ellada). On the other hand $A$. torrentium occurs in northern and north-eastern parts, with a degree of overlapping distribution with $A$. astacus in Thessaly and Central Macedonia. Both species' current distribution pattern is restricted to relatively pristine aquatic ecosystems (i.e. lakes, streams and upper river segments), thus relatively unaffected by human activities. However, there are still possible crayfish habitats that have not been surveyed and a great deal of information need to be verified on the field. Concerning A. leptodactylus, its present occurrence has been recently verified only in the River Evros close to the Greco-Turkish boarder, suggesting that the species should be regarded as indigenous in Greece. Concerning NICS, P. leniusculus forms a wellestablished satellite population in Lake Agras and co-occurs with A. torrentium.

Crayfish distribution in Greece is far more extended than it was thought in the past, as not only new populations were documented, but also species presence was confirmed for the first time after many years (i.e. A. leptodactylus and P. leniusculus). Massive mortalities have been reported since the early 1980's for $A$. astacus, following $P$. leniusculus introductions, but the populations currently seem to be in a recovering stage. In any case, imports (and exports), as well as translocations of crayfish should be strictly controlled, in order to protect the populations from possible future spread of diseases. Legislation measures should be reformed and augmented in order to protect native species, local populations and their habitats adequately. 
Finally, current research is very limited and is focusing mostly on the biology and hatching of the native species. However, there is a need for further research on species distribution. Overlapping occurrence and population dynamics of different species may provide interesting information on environmental requirements, ecophysiology and the importance of the anthropogenic impacts on them. Population diversity in most cases reflects genetic variation among populations and genetic research may give an important insight to evolution and biogeography of the species. Finally efforts in more applied research aspects such as reproduction, nutrition and diseases are necessary in order to advance our knowledge and precede to commercial scale crayfish farming.

\section{ACKNOWLEDGMENTS}

We would like to thank all the following collaborators (alphabetical order) for sending us information about the crayfish distribution in their prefecture: C. Diamandi (Karditsa Pref.), D. Evaggelidis and I. Kipou (Pella Pref.), P. Filos (Kastoria Pref.), C. Gogos, V. Gogos and N. Stavrou (Environmental Protection Society of Vrodismeni), M. Kalpenidou (Larissa Pref.), A. Kedrou (Preveza Pref.), F. Mane and E. Siaplaoura (loannina Pref.), I. Maragiani (Pieria Pref.), I. Michailidis, (Kilkis Pref.), C. Michailidis and P. Kehagias (Technological Educational Institute of Epirus), M. Nikolaidou (Grevena Pref.), A. Paleokostas (Ministry of Agricultural Development and Food), A. Papistas (Kozani Pref.), Prof. I. Paschos (Technological Educational Institute of Epirus), G. Pavlidis (Florina Pref.), D. Rizos and I. Tsamadias (Fthiotida Pref.), V. Saraglidou (Rodopi-Evros Pref.), S. Souflias (Trikala Pref.), N. Tatarakis (Serres Pref.), V. Theochari (National Agricultural Research Foundation).

\section{REFERENCES}

ALBRECHT H., 1982. Das System der europäischen Flußkrebse (Decapoda, Astacidae): Vorschlag und Begründung. Mitteilungen aus dem Hamburgischen Zoologischen Museum und Institut, 79, 187-210.

ALBRECHT H., 1983. Besiedlungsgeschichte und ursprünglish holozäne Verbreitung der europäischen Flußkrebse (Decapoda: Astacidae). Spixiana, 6, 61-77.

ALDERMAN D.J., 1996. Geographical spread of bacterial and fungal diseases of crustaceans. Revue Scientifique et Technique - Office International des Épizooties, 15 (2), 603-632.

ANDRÉ M., LAMY É., 1935. Les écrevisses de France. Chez les auteurs, Muséum national d'histoire naturelle, 61 Rue de Buffon, Paris, $89 \mathrm{p}$.

ARISTOTLE, History of Animals. Translators: Peck A.L. \& Forster E.S. Loeb Classical Library, London: W. Heinemann, 1965. 560 p.

ARTEMIADOU V., LAZARIDOU M., 2005. Evaluation score and interpretation index for the ecological quality of running waters in central and northern Hellas. Environmental Monitoring and Assessment, 110, 1-40.

ATHANASSOPOULOS G., 1935. Particularité de la distribution de l'ichthyofaune des eaux douces en Grèce. Verhandlungen der Internationalen Vereinigung für Theoretische und Angewandte Limnologie, Jahrgang 1934, 7, 117-121.

BALSS H., 1928. Süßwasserdecapoden aus Mazedonien. Zoolgischer Anzeiger, 75 (5/6), 120-122.

BOTT R., 1972. Besiedlungsgeschichte und Systematic der Astaciden West-Europas unter besonderer Berücksichtung der Schweiz. Revue Suisse de Zoologie, 79 (1), $387-408+4$ pl. 
BULGURKOV K., 1961. Sistematika, biologija i zoogeogravsko razprostranenie na sladkovodnite raci ot sem. Astacidae i sem. Potamobidae v Bylgarija. Izvestija na Zoologiceskija Institut s Muzei (Sofia), 10, 165-192.

CARBONNIER P., 1869. L'écrevisse: mœurs - reproduction, éducation. Paul Dupont, Paris, viii $+199 \mathrm{p}$.

DROUIN DE BOUVILLE R. de, 1906. Les repeuplements en écevisses. Bulletin des Séances de la Société des Sciences de Nancy, 7, 28-132 + 7 pl.

ECONOMIDIS P., 1995. Endangered freshwater fishes of Greece. Biological Conservation, 72, 201-211.

ECONOMIDIS P., BANARESCU P.M., 1991. The distribution and origins of freshwater fishes in the Balkan Peninsula, especially in Greece. Internationale Revue der Gesamten Hydrobiologie, 76 (2), 257-284.

EVAGGELIDIS E., 2001. I limni ton kiknon, o ygroviotopos Agra-Vritton-Nisiou (the swan lake, the wetland of Agra-Vritton-Nisiou). Edessa. 88 p. (in Greek).

FÜREDER L., MACHINO Y., 2002. A revised key of freshwater crayfish in Europe. Berichte des Naturwissenschaftlich-Medizinischen Vereins in Innsbruck, 89, 169$178+$ Erratum.

HARLIOGLU M.M., GÜNER U., 2006. Studies on the recently discovered crayfish, Austropotamobius torrentium (Schrank, 1803), in Turkey: morphological analysis and meat yield. Aquaculture Research, 37, 538-542.

HOLDICH D.M., 1999. The negative effects of established crayfish introductions. In: Crustacean Issues, vol. 11: Crayfish in Europe as alien species - how to make the best of a bad situation (GHERARDI, F. \& HOLDICH, D.M. eds). pp. 31-47. A.A. Balkema, Rotterdam.

HOLDICH D.M., 2002. Present distribution of crayfish in Europe and some adjoining countries. Bulletin Français de la Pêche et de la Pisciculture, 367, 611-650.

HOLDICH D.M., 2003. Crayfish in Europe - an overview of taxonomy, legislation, distribution, and crayfish plague outbreaks. In: Management \& Conservation of Crayfish (HOLDICH, D.M. \& SIBLEY, P.J. eds.), pp. 15-34. Environment Agency, Bristol.

HOLDICH D., WHISSON G., 2004. The First 30 Years: A history of the International Association of Astacology. International Association of Astacology, 248 p.

KALLISTORATOS G., 1990. Greece. Kalatutkimuksia-Fiskundersökningar (Helsinki), 3, 103-107. (Status of crayfish stocks, fisheries, diseases and culture in Europe: (WESTMAN K., PURSIAINEN M. \& WESTMAN P. eds.).

KARAMAN M.S., 1962. Ein Beitrag zur Systematik des Astacidae (Decapoda). Crustaceana, 3 (3), 173-191.

KARAMAN M.S., 1963. Studie der Astacidae (Crustacea, Decapoda). Hydrobiologia (The Hague), 22, 111-132.

KASTRITSI-KATHARIOU I., SKEPARIOTI E., 1990. Meleti aytohthona plythismou tis karavidas tou glykou nerou Astacus astacus proerxomenis apo ton Viotiko Kifisso (Study on indigenous population of freshwater crayfish Astacus astacus from Viotian River Kifisos). Athens University, Zoology Laboratory. 85 p. (in Greek).

KASTRITSI-KATHARIOU I., NIKOKIRAKIS M., ARMAKAS D., KAZANOGLOU A., 1994. Meleti tis karavidas Astacus astacus proerxomenis apo fysiko plythismo viotyopou ston Orhomeno Viotias (Study on the crayfish Astacus astacus from the native population in Orchomenos Viotias. $2^{\text {nd }}$ Report to the Greek Ministry of Agriculture. Athens University, School of Biology, Zoology Department, Athens. 115 p. (in Greek). 
KEVREKIDIS K., PAPALEXIOU E., SBILIRI E., PASSAS N., KIRKALATSLIS P., 1999. Eglimatismos kai ektrofi tis karavidas Astacus astacus Linnaeus sto ergastirio (Acclimation and farming of crayfish Astacus astacus Linnaeus in the laboratory). Alieftika Nea, 216, 95-98 (in Greek).

KINZELBACH R., 1986. The southern limit of the crayfishes species Astacus torrentium and $A$. astacus in Greece. Zoology in the Middle East (Heidelberg), 1, 145-146.

KIOUSIS D., 2006 (January 21st). Orini Karditsa: I kardia tis Elladas (Mountainous Karditsa: the heart of Greece). Kathimerini (Taxidia suppl.), 2-7.

KOUKOURA A., 1973. Simboli is tin meletin ton dekapodon karkinoidon tis Ellados (Contribution to the study of decapod crustaceans in Greece). Elleniki Okeanologia kai Limnologia (Athens), 11, 745-769 + 3 pl.

KOUTRAKIS E., KATSAITI L., KALLIANIOTIS A., TSIKLIRAS A., DIAFAS N., BOBORI C.D., ECONOMIDIS P.S., 2003. The aquatic macrofauna of Cave Aggitis (Maaras, Drama). Preliminary results. Proceedings of the $11^{\text {th }}$ Hellenic Congress of Ichthyologists. Preveza, Greece 10-14 March 2003, p. 83-86.

KOUTRAKISE.T., MACHINOY., KALLIANIOTISA., HOLDICHD.M.,2005a. Austropotamobius torrentium (Schrank, 1803) in the Aggitis Cave (northern Greece). Is it a cavedwelling species? Bulletin Français de la Pêche et de la Pisciculture, 376/377, 529-538.

KOUTRAKIS E.T., KATSAITI L., KALLIANIOTIS A., ECONOMIDIS P.S., 2005b. The stone crayfish Austropotamobius torrentium in the Aggitis Cave (River Aggitis springs, Drama). Proceedings of the $12^{\text {th }}$ Hellenic Congress of Ichthyologists. Drama, Greece 13-16 October 2005, p. 316-319 (in Greek with English abstract).

LAMBROPOULOU D.A., SAKKAS V.A., HELA D.G., ALBANIS T.A., 2002. Application of solid-phase microextraction in the monitoring of priority pesticides in the Kalamas River (N.W. Greece). Journal of Chromatography A, 963, 107-116.

LAURENT P.J., 1997. Introductions d'écrevisses en France et dans le monde, historique et conséquences. Bulletin Français de la Pêche et de la Pisciculture, 344/345, 345-356.

LEWIS S.D., 2002. Pacifastacus. In: Biology of Freshwater Crayfish, pp. 511-540 + plates 24 \& 42 (D.M. HOLDICH ed.). Blackwell Science Ltd, Oxford, UK.

LOWERY R.S., HOLDICH D.M., 1988. Pacifastacus leniusculus in North America and Europe, with details of the distribution of introduced and native crayfish species in Europe. In: Freshwater Crayfish: biology, management and exploitation (D.M. HOLDICH.\& R.S. LOWERY eds.), pp. 283-308 + 426-479. Croom Helm, London.

MACHINO Y., FÜREDER L., 2005. How to find a stone crayfish Austropotamobius torrentium (Schrank, 1803): a biogeography study in Europe. Bulletin Français de la Pêche et de la Pisciculture, 376/377, 507-517.

MACHINO Y., HOLDICH D.M., 2006. Distribution of crayfish in Europe and adjoining countries: updates and comments. Freshwater Crayfish, 15, 292-323.

NEOPHYTOU C., TIAGOS P., REVIS D., 1993. Meleti tis pyknotitas ton makro-venthikon organismon sto rema "Myloi" Angistrou (Study of the density of macro-benthic organisms in the creek "Myloi" Angistrou). Geotechnika Epistimonika Themata (Thessaloniki), 4 (4), 44-71 (in Greek).

NIKOLAOU C., 2004. Biologia tis karavidas Astacus fluviatilis: I periptosi tis karavidas tou potamou Kalama kai tis texnitis limnis Aoou (Biology of crayfish Astacus fluviatilis: the case of crayfish in the river Kalamas and artificial Lake of Aoos). Graduate Thesis, Department of Aquaculture \& Fisheries, Technological Educational Institute of Epirus, 117 p. (in Greek). 
O.I.E., 2000. Crayfish plague. In: Diagnostic Manual for Aquatic Animal Diseases. $3^{\text {rd }}$ edition. Office International des Épizooties (OIE), Paris, p. 227-230.

PASCHOS I., KAGALOU I., 1995. Diaxiristiki meleti Limnis Pamvotidas (Management study of Lake Pamvotis). Prefecture of loannina, Epirus, Greece, 600 p. (in Greek).

PERDIKARIS C., NATHANAILIDES C., ERGOLAVOU, A., PASCHOS I. 2005a. Freshwater crayfish (Astacus astacus L.) in the river Kalamas: species and sex distinction, sex ratio, length-frequency analysis and growth. Proceedings of the $12^{\text {th }}$ Hellenic Congress of Ichthyologists. Drama, Greece 13-16 October 2005, pp. 180-184. (in Greek with English abstract).

PERDIKARIS C., KOUTRAKIS E., SARAGLIDOU V., 2005b. Occurrence of narrow-clawed crayfish Astacus leptodactylus (Eschscholtz, 1823) in the River Evros (Thrace, Greece). Proceedings of the $12^{\text {th }}$ Hellenic Congress of Ichthyologists. Drama, Greece 13-16 October 2005, pp. 320-322. (in Greek with English abstract).

PERDIKARIS C., KOUTRAKIS M., MACHINO Y., 2005c. Overview of crayfish situation in Greece. Crayfish News-IAA Newsletter, December 2005, 27 (4), 5-7.

PERDIKARIS C., KOUTRAKIS E., SARAGLIDOU V., MARGARIS N., 2007. Occurrence of the narrow-clawed crayfish Astacus leptodactylus Eschscholtz, 1823 in the River Evros in Greece. Bulletin Français de la Pêche et de la Pisciculture, 385, 45-52.

SAVVIDIS G., 2005a. Ekthesi-gnomatefsi epi tou fenomenou tou mazikou thanatou karavidon ston Potamo Kalama kai tous parapotamous tou Gormo kai Limpousda stin periohi Parakalamou tou N. Ioanninon (Report on the massive mortalities incident in Kalamas River and its tributaries Gorno and Limpousda, Parakalamos, loannina Prefecture). Report n 1305/15-9-2005, National Agricultural Research Foundation, 11 p. (in Greek).

SAVVIDIS G., 2005b. Simpliromatiki ekthesi epi tou fenomenou tou mazikou thanatou karavidon ston Potamo Kalama kai tous parapotamous tou Gormo kai Limpousda stin periohi Parakalamou tou N. Ioanninon (Supplementary report on the massive mortalities incident in Kalamas River and its tributaries Gorno and Limpousda, Parakalamos, loannina Prefecture). Report n 1527/31-10-2005, National Agricultural Research Foundation, 3 p. (in Greek).

SOUTY-GROSSET C., GRANDJEAN F., RAIMOND R., FRELON M., DEBENEST C., BRAMARD M., 1997. Conservation genetics of the white-clawed crayfish Austropotambius pallipes: usefulness of the mitochondrial DNA marker. Bulletin Français de la Pêche et de la Pisciculture, 347, 677-692.

SOUTY-GROSSET C., HOLDICH DM., NOËL P.Y., REYNOLDS J.D. and HAFFNER P. (eds). 2006. Atlas of crayfish in Europe. Collection Patrimoines Naturels, vol. 64, 187 p. Muséum National d'Histoire Naturelle, Paris.

STANCOMB W., 2000. The William Stancomb Collection of coins of the Black Sea region. Sylloge Nummorum Graecorum, vol. 11, Oxford: Oxford University Press, 136 p. (accessed from http://www.sylloge-nummorum-graecorum.org/, 20 July 2006).

SUBCHEV M., STANIMIROVA L., 1998. Razprostranenie na pravite sladkovodni raci (Crustacea: Decapoda) i tehnite epibionti ot rod Branchiobdella (Annelida: Branchiobdellae), Hystricosoma chappuisi Michaelsen, 1926 (Annelida: Oligochaeta) i Nitocrella divaricata (Crustacea: Copepoda) v Bylgarija. Historia Naturalis Bulgarica, 9, 5-18.

SWAHN J.Ö., 2004. The cultural history of crayfish. Bulletin Français de la Pêche et de la Pisciculture, 372/373, 243-261.

THÉOCHARIS V.S., 1986. La pêche à l'écrevisse dans la région d'Hipiros en Grèce. L'Astaciculteur de France, 8, 4-10. 
TRONTELJ P., MACHINO Y., SKET B., 2005. Phylogenetic and phylogeographic relationships in the crayfish genus Austropotamobius inferred from mitochondrial COI gene sequences. Molecular Phylogenetics and Evolution, 34, 212-226.

WESTMAN K., PURSIAINEN M., WESTMAN P., 1990. The situation of crayfish stocks, fisheries, diseases and crayfish culture in Europe - a review. KalatutkimuksiaFiskundersökningar (Helsinki), 3, 5-31. (Status of crayfish stocks, fisheries, diseases and culture in Europe: WESTMAN K., PURSIAINEN M. \& WESTMAN P. eds.). 